\title{
A Critical Review of Theory in Social Work Journals: A Replication Study
}

\author{
Carolyn S. Gentle-Genitty \\ Virgil Gregory \\ Corey Pfahler \\ Misty Thomas \\ Lisa Lewis \\ Kim Campbell \\ Kathy Ballard \\ Kathy Compton \\ James G. Daley
}

\begin{abstract}
The purpose of this paper is multifold. Key aspects discussed include exploring the extent of theory discussion and progression in social work journals for the year 2004; discussing the necessity of theory in social work research and practice; reviewing previous research literature regarding evaluation of theory discussion and progression; proposing criteria for defining theory in social work journals; and presenting findings from the current study concerning theory discussion and progression in social work journals. Results: Of the 1,168 articles reviewed from 37 journals, 71 (approximately 6\%) met the criteria for theory development with empirical base. Thus, a minimal number of articles ( 3 out of 71 or $4.2 \%$ ) evaluated, based on the criteria in the theory quality scale (Table 1), received high quality ratings. Conclusion: Based on the results yielded by the analysis, we assert that social workers need to make a conscious effort to include theory in practice decisions.
\end{abstract}

Keywords: Theory, social work theory, empirical assessment of theory, social work practice, theory progression, human behavior, and the social environment (HBSE)

$\mathrm{T}$ heories provide a lens to help us frame the complex interplay between humans and their environment. A large part of this understanding occurs within the context of practice, specifically social work practice. Bartlett (2003) and Pinderhughes (1996) define this practice as one that endeavors to define a roadmap of a myriad of methods, knowledge, sanctions, values, and purposes for social workers. This practice, the habitual actions of

Carolyn S. Gentle-Genitty, Virgil Gregory, Corey Pfahler, Misty Thomas, Lisa Lewis, Kim Campbell, Kathy Ballard, and Kathy Compton are doctoral students, and James G. Daley, Ph.D. is associate professor at the Indiana University School of Social Work, Indianapolis, IN, 46202-5156.

Copyright $^{\bullet} 2007$ Advances in Social Work Vol. 8 No. 1 (Spring 2007) 62-80.

Indiana University School of Social Work. 
actors, and the rules that govern their field (Andermahr, Lovell, \& Wolkowitz, 1997), enables social workers, retrospectively and prospectively, to explain and forecast relationships and actions of human behavior (Thyer, 2001). Nestled neatly within the purposes of social work, social work practice provide skills "to identify, analyze, implement empirically based interventions to achieve client goals; apply empirical knowledge; evaluate program outcomes and provide leadership in the promotion of social and economic justice" (Schriver, 2004, p. 5). There are still questions about social work practice and what it is expected to do. For instance, what actually helps to frame social work practice? How do social workers justify practice approaches utilized to attain their goals? Answers to these questions help to shape the current discussion. The authors purport that theory and theory progression is what ties these questions together.

The question concerning how theory is disseminated among social work professionals is raised. Journals serve as a major source for theory dissemination (Lindsey \& Kirk, 1992). For this reason, theory development and discussion is an important component for researchers to address, as well as for journals to publish. The purpose of this paper is multifold:

1.To explore the extent of theory discussion and progression in social work journals for the year 2004;

2.To discuss the necessity of theory in social work research and practice;

3. To review pertinent literature concerning previous research conducted regarding evaluation of theory discussion and progression in social work journals;

4. To propose criteria for defining theory in social work journals;

5. To present findings from the current study concerning theory discussion and progression in social work journals.

\section{DEFINING THEORY}

Social work practice is framed by theory and its modus operandi. Theory, Turner (1996) outlines, "emerges from the process of ordering facts in a meaningful way" (p. 3). He highlights that theory spotlights notable patterns and relationships that bring homeostasis and stability to the intricacies of practice. Failure to do this leaves practice to "guesswork" and "impressionistic responses" to client situations (Turner, 1996). A key limitation of theory for practice, Turner (1996) warns, is when it becomes "overly cerebral and mechanistic, stressing labeling and classifying, rather than on the individuality of each client and situation it can become an end in itself" (p. 13). A great limitation of bridging theory to practice is that it has become too cerebral. On a whole, the result is that direct and indirect practitioners do not see its relevance to their daily work (Rosen, Proctor, \& Staudt, 2003; Thyer, 2001).

Theory may also be defined as "a reasoned set of propositions, derived from and supported by established evidence, which serves to explain a group of phenomena" (Schriver, 2001, p. 119). On the other hand, Robbins and colleagues suggest 
that theories "consist of a series of relatively abstract and general statements that collectively purport to explain (answer the question "why?") some aspect of the empirical world (the "reality" known to us directly or indirectly through our senses)" (p. 5). Theory provides practitioners with a systematic method to conceptualize information about individuals, their behavior, and the contexts in which they interact and live. The importance of theory is often emphasized (Payne, 2005; Robbins et al., 1999; Schriver, 2001; Turner, 1996) and, realizing that social work is at a critical juncture (Finn \& Jacobson, 2003), there is a current call for theory to play a more integral part in practice-a part that takes the "guesswork" from practice, allowing relationships to be defined via patterns and a specific theoretical lens (Turner, 1996), while also empowering social workers to validate their chosen methods of intervention.

\section{IMPORTANCE OF THEORY IN SOCIAL WORK PRACTICE}

Rightly so, there has been much debate about the importance of theory in social work practice (Gomory, 2001; Thyer, 1994). The preceding paragraphs give a brief overview of such a debate. For instance, Thyer adopts the stance that teaching and the utilization of theory among undergraduate and master's level social work students is "largely a waste of time" (p. 148). Thyer provides the following three explanations for this stance. First, social work educators lack skills to adequately teach social work theory. Second, the majority of theories taught in the social work profession are incorrect. Teaching incorrect theories may lead to ineffective methods used in social work. Third, while theory attempts to explain outcomes for treatment effectiveness, many outcomes may be explained by other theories or factors. Thyer asserts that, recognizing that outcomes may be explained by various theoretical explanations, is unnecessarily complicated.

Conversely, Gomory (2001) refutes Thyer's (1994) stance regarding the importance of teaching theory in social work, as he feels that the use of theory to guide social work research and practice is of major importance. Gomory emphasizes the use of "trial and error" among social work professionals (p. 47) to develop educated and autonomous opinions of how theory should guide research and be applied to practice interventions.

Specifically, the use of theory in social work practice is essential; it provides many more reasons, irrespective of the debate. These reasons may include but are not be limited to the provision of guidelines for practice and policy, treatment and intervention development, and direct social work research. General guidelines provided by social work theory may be useful in providing information about what policies are necessary to change conditions for target groups and vulnerable populations (Robbins et al., 1999). The framework provided by theory may be useful by social workers to develop treatment and intervention plans to enhance the functioning of individuals and society (Robbins et al., 1999; Schriver, 2001). Lastly, theory may be used to direct social work research (Robbins et al., 1999). Research provides a foundation to explain how and why certain conditions and behaviors occur and provides an approach to effectively guide interventions. 


\section{EVALUATION OF THEORY QUALITY AND PROGRESSION}

While there is debate as to whether the use of theory is essential in the profession of social work (Gomory, 2001; Robbins et al., 1999; Thyer, 1994), it may be asserted that theory is important to knowledge development. The use of theory to guide research and inform practice is not infallible. However, when examined under a critical lens, theory provides social workers with guidelines to explain and predict outcomes (Schriver, 2001).

Journals are one of the primary means of knowledge development and dissemination among social work professionals. Because journals are the primary means through which knowledge of theory is disseminated, these questions are posed: How do social work professionals define the value and credibility of a particular theory? How does one evaluate the quality of a particular journal in which a theory is published? When evaluating the value and credibility of a theory, it is necessary to discuss two topics: theory discussion and theory progression. Theory discussion may be simply stated as that discussion of theory within the context of a journal article. Discussion of theory may range from merely mentioning a particular theory to discussing the basic premises of that theoretical construct. Including discussion of theory in a journal article does not indicate an in-depth examination of the theory. Rather, theory discussion may be defined as a superficial description of the theory that does not include exploration of the components or empirical base of the theory. Theory progression takes theory discussion further-to explore the components of the theory, examine the empirical basis and supporting arguments, and provide knowledge concerning future development of the theory.

A number of authors have developed criteria for evaluating theory quality and development (Fischer, 1973; Payne, 2005; Robbins et al., 1999; Witkin \& Gottschalk, 1988). These authors propose a set of criteria that they believe is adequate for evaluating theory quality and development. Payne (2005) provides a critique of five authors' framework for evaluating theory quality and development. However, he does not propose a synthesizing rating system to evaluate theory, but merely a critique (Payne, 2005).

Fischer (1973) proposed a framework for analysis of theories of therapy. Fischer's main goals for the development of this framework were twofold. One goal of the framework was to serve as a guide for addressing questions raised by clinical therapies. A second goal was to provide guidance in evaluating these theories based upon the questions raised. Fischer provided five basic areas in which clinical theories may be analyzed: 1) structural characteristics, 2) characteristics as a theory of therapy, 3) empirical status, 4) assumptions about the nature of man and moral implications, and 5) applicability to social work. Fischer also provided a four-point criterion scale for theory rating.

Robbins and others (1999) proposed criteria for evaluating theory in social work practice. These authors offer three criteria for theory evaluation: 1) theories for social work practice should be consistent with social work values and ethics; 2) theories for social work practice should be subjected to scientific scrutiny, methodologically sound research, and be verifiable, and 3) theories for social 
work practice should do no harm. Each criterion and the application of the criterion to social work practice are discussed in detail.

Witkin and Gottschalk (1988) state that the traditional criteria often utilized to evaluate social work theory are inadequate. The authors propose the utilization of four additional criteria for theory evaluation. Criterion one states that theory should be explicitly critical. Criterion two states that the theory should recognize humans as active agents. Criterion three states that the theory should account for the life experiences of the client. Criterion four states that the theory should promote social justice. The authors provide an explanation for each criterion and its application. Using this framework, the authors assert that theories that correspond to these criteria are preferable to theories that do not meet them.

While several authors (Fischer, 1973; Payne, 2005; Robbins et al., 1999; Witkin \& Gottschalk, 1988) have proposed criteria for theory evaluation, the researchers have found these criteria to be inadequate. The researchers developed criteria to ensure that the journals selected for review would reflect social work content. After selecting journals for review, the researchers reviewed articles in the selected journals based on criteria to determine if the article contained theory discussion. If theory discussion was present to a certain extent, the researchers further evaluated the theory discussion in that article against a second set of criteria. The following methods section provides an explication of the procedures that guided our inquiry. Admittedly, this statement could also use some work.

\section{METHOD}

Two-hundred and sixty-eight social work journals from 2004 were selected for review. These journals were selected based on social work journals available at the Indiana University Purdue University (IUPUI) University Library and from the website http://cosw.sc,edu/swan/media.html. These journals were considered "social work" journals by the IUPUI library. Seventeen theory progression team members reviewed the two lists for repetition and condensed the list to 220 journals. These 220 journals were cross-referenced with The Authors Guide to Social Work Journals (NASW, 1997) for congruence with the social work profession. This process further narrowed the list to 54 social work journals. Theory progression team members developed a list of criteria to ensure that the journals would reflect social work content. The criteria were as follows: the journal must be peerreviewed and meet at least one of the following criteria:

1. Published by a school of social work or a professional social work organization.

2. The mission statement places primary emphasis on social work or social workers.

3. "Social Work" appears in title of the journal.

To ensure inter-rater reliability, team members independently reviewed three articles for theory quality. An inter-rater reliability (kappa) of .85 was obtained from all raters prior to starting the review process. The Theory Quality Scale included nine criteria. Each criterion was a statement regarding the article's fulfillment of a specific characteristic and received a rating from 1 to 5 (Table 1). If the article fully satisfied the purpose of the specific criterion in question, that arti- 


\begin{tabular}{|l|}
\hline Table 1: Criteria for Theory Quality \\
\hline Criteria \\
\hline Components of theory are described in a tight, internally consistent \\
framework \\
Clearly describes each variable within the theory \\
Clearly operationalizes the relationship between the variables within \\
the theory \\
Clearly describes goals or outcomes intended with theory \\
Clearly describes the boundaries or limitations of the theory \\
Clearly describes the empirical data that support the premises of theory \\
Clearly builds upon previous studies that demonstrate the efficacy of the \\
theory \\
Clearly concludes with specific next steps for theory progression \\
Clearly expresses the framework for exploring and/or responding to issues \\
of social justice \\
\hline $\begin{array}{l}\text { Scoring: } 5=\text { strongly agree } 4=\text { moderately agree } 3=\text { slightly agree } 2=\text { moderately disagree } 1=\text { strongly } \\
\text { disagree }\end{array}$ \\
\hline
\end{tabular}

cle received a score of 5 , which indicates full credit for that criterion. If an article completely failed to satisfy the criterion in question, that article was given a score of 1 . Subsequent to determining inter-rater reliability, team members reviewed the 54 journals against criteria put forth by the theory progression team. This narrowed the list to 41 journals. These 41 journals were divided among seven team members. The team members reviewed each journal and its respective articles for the year 2004. Due to pragmatic reasons such as inability to access journals electronically or manually, and due to some journals no longer being in publication, four journals could not be accessed.

One-thousand one-hundred and sixty-eight articles were reviewed for inclusion of theory. All of the articles in each of the journals were rated according to the Journal Inclusion of Theories Scale. The articles were searched via online databases, including Ebso Host, Expanded Academic, ASAP, and via the library of IUPUI catalog of electronic journals. When journals were not available for review electronically but were accessible manually, hard copies of the journals were obtained and their subsequent articles reviewed. Articles were evaluated according to the overall role that theory played in the article, the extent to which the theory was included in the article, and the presence or absence of empirical evidence in the article. This rating scale ranged from 0 to 6 to indicate articles that had no empirical or theoretical links all the way to articles whose purpose was theory development and analyzed empirical data to support its development (Table 2). Articles that received a rating of 5 or 6 on the Journal Inclusion of Theories Scale were further reviewed utilizing the Theory Quality Scale. Subsequent to reviewing each article, a sum score for the number of articles that received a particular score on the Inclusion of Theories Scale was calculated.

All of the journals with articles that were included in the final analysis were classified according to the Educational Policy and Accreditation Standards (EPAS) 


\begin{tabular}{|c|c|c|c|c|}
\hline Score & Rating & $\begin{array}{l}\text { \# of } \\
\text { Articles }\end{array}$ & $\begin{array}{l}\text { Sum } \\
\text { Score }\end{array}$ & $\begin{array}{l}\text { \% of } \\
\text { Total }\end{array}$ \\
\hline 6 & $\begin{array}{l}\text { Theory development with empirical base as } \\
\text { the focus of the article (TDE) }\end{array}$ & & & \\
\hline 5 & $\begin{array}{l}\text { Theory development/explanation as the focus } \\
\text { of the article (TDF) }\end{array}$ & & & \\
\hline 4 & Empirical study that has theory links (ET) & & & \\
\hline 3 & non-empirical article with theory links (NETL) & & & \\
\hline 2 & Empirical study with brief theory links (EBT) & & & \\
\hline 1 & Empirical study with no theory links (ENT) & & & \\
\hline 0 & Studies with no empirical or theory links (NET) & & & \\
\hline TOTAL & & & & $100 \%$ \\
\hline
\end{tabular}

content areas. These content areas include Values and Ethics, Diversity, Populations-at-Risk and Social and Economic Justice, Human Behavior and Social Environment, Social Welfare Policy and Services, Social Work Practice, Research, and Field Education. The publishers' descriptions of their respective journals were used to classify the journals according to the EPAS content areas. The descriptions of each of the respective journals were found online, most via publisher websites. The journal classification process involved treating the content areas as if they were mutually exclusive and exhaustive; therefore, all of the journals were classified according to only one of the eight content areas. All journal descriptions referenced more than one EPAS content area; therefore, the content area classification was based on the journal's primary purpose and title. Admittedly, due to each journal referencing several of the EPAS content areas, the process of classification was somewhat subjective. This subjectivity was decreased by using the journals' mission and other key descriptive traits as the primary determinants that guided the classification process. The results suggest, however, that practice journals are much more theory-driven than any other journal, despite the fact that the number one rated article was a research journal.

\section{RESULTS}

Of the 1,168 articles that were reviewed, 71 (approximately 6\%) met the criteria for theory development with empirical base (TDE) or theory development/ explanation as the focus of the article (TDF). Table 3 includes a breakdown of journal ratings by degree of discussion of theory (based on journal and theory evaluation criteria, Table 2) for each of the 1,168 articles reviewed. Given that the purpose of this study was to explore the extent of overall theory discussion and progression in social work journals for the year 2004, the names of the journals that were reviewed are not disclosed, rather, the journals are represented by numerical codes, as it was not our intent to identify which journals support the importance of theory discussion as indicated by articles chosen for publication. Overall, the results illustrate minimal focus on theory within the 37 journals selected for 


\begin{tabular}{|c|c|c|c|c|c|c|c|c|c|c|}
\hline Journal & $\begin{array}{c}\text { Journal } \\
\text { Type }\end{array}$ & TDE & TDF & ET & NETL & EBT & ENT & Net & $\begin{array}{c}\text { Total } \\
\text { Articles }\end{array}$ & $\begin{array}{l}\% \text { TDE } \\
\text { or TDF }\end{array}$ \\
\hline 22 & Research & 1 & 3 & 0 & 0 & 2 & 3 & 0 & 9 & 44.44 \\
\hline 7 & Practice & 10 & 7 & 5 & 1 & 9 & 14 & 1 & 46 & 36.96 \\
\hline 36 & $\begin{array}{l}\text { Social } \\
\text { Service \& } \\
\text { Social } \\
\text { Welfare } \\
\text { Policy }\end{array}$ & 0 & 2 & 0 & 1 & 2 & 0 & 1 & 6 & 33.33 \\
\hline 6 & Practice & 0 & 6 & 1 & 11 & 1 & 2 & 3 & 24 & 25.00 \\
\hline 12 & $\begin{array}{l}\text { Population } \\
\text { At-risk }\end{array}$ & 0 & 3 & 0 & 0 & 5 & 2 & 5 & 15 & 20.00 \\
\hline 15 & HBSE & 2 & 4 & 8 & 3 & 8 & 7 & 3 & 35 & 20.00 \\
\hline 30 & HBSE & 5 & 2 & 0 & 4 & 1 & 11 & 15 & 38 & 18.42 \\
\hline 26 & Practice & 0 & 2 & 0 & 2 & 1 & 9 & 7 & 21 & 9.52 \\
\hline 20 & Practice & 0 & 2 & 1 & 0 & 3 & 16 & 1 & 23 & 8.70 \\
\hline 33 & $\begin{array}{l}\text { Field } \\
\text { Education }\end{array}$ & 0 & 2 & 1 & 3 & 2 & 5 & 11 & 24 & 8.33 \\
\hline 3 & Practice & 0 & 4 & 3 & 14 & 16 & 18 & 7 & 62 & 6.45 \\
\hline 14 & Practice & 1 & 0 & 1 & 2 & 0 & 8 & 4 & 16 & 6.25 \\
\hline 13 & Practice & 1 & 1 & 1 & 3 & 4 & 17 & 6 & 33 & 6.06 \\
\hline 2 & HBSE & 0 & 1 & 0 & 6 & 3 & 5 & 3 & 18 & 5.55 \\
\hline 10 & Practice & 0 & 2 & 0 & 0 & 1 & 14 & 21 & 38 & 5.26 \\
\hline 24 & Practice & 0 & 3 & 4 & 8 & 11 & 22 & 10 & 58 & 5.17 \\
\hline 5 & Research & 0 & 1 & 1 & 14 & 0 & 0 & 4 & 20 & 5.0 \\
\hline 4 & Research & 1 & 0 & 3 & 2 & 7 & 8 & 2 & 23 & 4.35 \\
\hline 11 & Practice & 1 & 0 & 3 & 0 & 2 & 18 & 0 & 24 & 4.17 \\
\hline 29 & Practice & 1 & 0 & 4 & 7 & 2 & 10 & 5 & 29 & 3.45 \\
\hline 25 & $\begin{array}{l}\text { Social } \\
\text { Services } \\
\& \text { Social } \\
\text { Welfare } \\
\text { Policy }\end{array}$ & 0 & 1 & 1 & 0 & 4 & 17 & 7 & 30 & 3.33 \\
\hline 23 & Practice & 0 & 1 & 2 & 1 & 7 & 30 & 2 & 43 & 2.33 \\
\hline 32 & $\begin{array}{l}\text { Social } \\
\text { Services } \\
\& \text { Social } \\
\text { Welfare } \\
\text { Policy }\end{array}$ & 1 & 0 & 3 & 3 & 2 & 37 & 23 & 69 & 1.45 \\
\hline 1 & HBSE & 0 & 0 & 4 & 9 & 0 & 2 & 63 & 78 & 0.0 \\
\hline 19 & Practice & 0 & 0 & 0 & 1 & 4 & 10 & 0 & 15 & 0.0 \\
\hline 21 & Diversity & 0 & 0 & 0 & 0 & 3 & 9 & 0 & 12 & 0.0 \\
\hline 27 & Practice & 0 & 0 & 0 & 10 & 2 & 2 & 20 & 34 & 0.0 \\
\hline
\end{tabular}




\begin{tabular}{|c|c|c|c|c|c|c|c|c|c|c|}
\hline Journal & $\begin{array}{c}\text { Journal } \\
\text { Type }\end{array}$ & TDE & TDF & ET & NETL & EBT & ENT & Net & $\begin{array}{c}\text { Total } \\
\text { Articles }\end{array}$ & $\begin{array}{l}\% \mathrm{TDE} \\
\text { or TDF }\end{array}$ \\
\hline 28 & $\begin{array}{l}\text { Social } \\
\text { Services \& } \\
\text { Social } \\
\text { Welfare } \\
\text { Policy }\end{array}$ & 0 & 0 & 1 & 4 & 1 & 13 & 14 & 33 & 0.0 \\
\hline 17 & $\begin{array}{l}\text { Field } \\
\text { Education }\end{array}$ & 0 & 0 & 0 & 1 & 1 & 3 & 9 & 14 & 0.0 \\
\hline 8 & HBSE & 0 & 0 & 0 & 11 & 0 & 0 & 13 & 24 & 0.0 \\
\hline 31 & $\begin{array}{l}\text { Field } \\
\text { Education }\end{array}$ & 0 & 0 & 0 & 5 & 1 & 11 & 26 & 43 & 0.0 \\
\hline 9 & $\begin{array}{l}\text { Social } \\
\text { Services } \\
\& \text { Welfare } \\
\text { Social } \\
\text { Policy }\end{array}$ & 0 & 0 & 0 & 6 & 9 & 9 & 13 & 37 & 0.0 \\
\hline 16 & $\begin{array}{l}\text { Social } \\
\text { Services } \\
\text { \&Welfare } \\
\text { Social } \\
\text { Policy }\end{array}$ & 0 & 0 & 0 & 5 & 0 & 4 & 10 & 19 & 0.0 \\
\hline 34 & Practice & 0 & 0 & 0 & 1 & 1 & 0 & 13 & 15 & 0.0 \\
\hline 35 & $\begin{array}{l}\text { Field } \\
\text { Education }\end{array}$ & 0 & 0 & 2 & 1 & 2 & 4 & 15 & 24 & 0.0 \\
\hline 18 & Practice & 0 & 0 & 1 & 1 & 0 & 21 & 10 & 33 & 0.0 \\
\hline 37 & Practice & 0 & 0 & 3 & 5 & 27 & 22 & 26 & 83 & 0.0 \\
\hline TOTAL: & & 24 & 47 & & & & & & 1,168 & \\
\hline \multicolumn{11}{|c|}{$\begin{array}{l}\text { TDE=Theory discussion with empirical base as the focus of the article; } \boldsymbol{T D F}=\text { Theory discussion as } \\
\text { the focus of the article; } \boldsymbol{E T}=\text { Empirical study that has theory links; } \boldsymbol{N E T L = N o n - E m p i r i c a l} \text { article with } \\
\text { theory links; } \boldsymbol{E B T}=\text { Empirical study with brief theory links; } \boldsymbol{E N T}=\text { Empirical study with no theory } \\
\text { links; } \boldsymbol{N E T = S t u d i e s ~ w i t h ~ n o ~ e m p i r i c a l ~ o r ~ t h e o r y ~ l i n k s . ~}\end{array}$} \\
\hline
\end{tabular}

review. Twelve of the 37 journals, or $32 \%$, contained no articles with TDE or TDF, while three of the 37 journals, or $8 \%$, contained $30 \%$ or more articles with TDE or TDF.

Articles containing TDE or TDF were further evaluated for theory quality using the criteria in the theory quality scale (Table 1). The purpose of this two-step evaluation process was to identify articles that focused on theory development with empirical base or theory development/explanation (TDE or TDF) as a first step followed by a second assessment of the quality of theory discussion. Factors considered in assessing the quality of theory discussion, included a tight internally consistent framework, operationalization of variables, limitations of theory, identification of steps for theory progression, or consideration of theory with regard to social justice. The theory quality scale (Table 1) was developed based on the work of Daley and others (2005) and factors blended from the models described 
in the "evaluation of theory quality and progression" section. Table 2 presents the discussion of theory quality scores for those articles containing TDE or TDF.

Each theory progression team member reviewed articles containing TDE or TDF using the nine criteria are listed in Table 4 . Each of the 71 articles containing TDE or TDF were evaluated by one team member and was assigned a rating ranging from 5 to 1 (strongly agree to strongly disagree, respectively) for each of the nine criteria in Table 1 . The rater then computed the mean score for the article (total divided by nine). The mean score for the 71 articles was 3.7, with three articles scoring 5, 21 articles scoring 4 or higher, and nine articles scoring 3 or less. Thus, a minimal number of articles ( 3 out of 71 or $4.2 \%$ ), which were evaluated based on the criteria in Table 1, received high quality ratings.

\begin{tabular}{|c|c|c|}
\hline Theory & Rating & Author \& Year of Publication \\
\hline Queer Theory & 45 & McPhail, 2004 \\
\hline Housework Theory & 45 & Kroska, 2004 \\
\hline Feminist Theory & 45 & Chafetz, 2004a \\
\hline ABCX Model and Resiliency & 44 & Vandsburger \& Biggerstaff, 2004 \\
\hline Role Theory & 44 & Landry-Meyer \& Newman, 2004 \\
\hline Feminist Theory & 43 & Mack-Canty \& Wright, 2004 \\
\hline Feminist Theory & 43 & Walker, 2004 \\
\hline Feminist Theory & 43 & Baber, 2004 \\
\hline Gender Construction Theory & 43 & Zuo, 2004 \\
\hline Feminist Theory & 43 & Chafetz, 2004b \\
\hline Social Capital Theory & 42 & Anguiano, 2004 \\
\hline Feminist Theory & 42 & Allen, 2004 \\
\hline Nested Ecological Theory & 41 & Cottrell \& Monk, 2004 \\
\hline Transtheoretical Model & 40 & Corden \& Somerton, 2004 \\
\hline The Theory of Mindful Space & 40 & Burlae, 2004 \\
\hline Family Systems Theory & 40 & Vandervalk et al., 2004 \\
\hline Risk and Resilience & 39 & Corcoran \& Nichols-Casebolt, 2004 \\
\hline \multicolumn{3}{|l|}{ Feminist Theory } \\
\hline - Queer Theory, & 39 & Wood, 2004 \\
\hline - Gender Theory & & \\
\hline - Social Theory, & & \\
\hline - Queer Body Theory & & \\
\hline - Disability Theory & & \\
\hline Responsive Regulation & 39 & Pennell, 2004 \\
\hline Teaching Family Life Cycle & 38 & Richman \& Cook, 2004 \\
\hline Social-Psychological Attitude Theory & 37 & Kahng \& Mowbray, 2004 \\
\hline
\end{tabular}




\begin{tabular}{|c|c|c|}
\hline Theory & Rating & Author \& Year of Publication \\
\hline $\begin{array}{l}\text { Attachment Theory } \\
\text { - Object Relations Theory } \\
\text { - Psychoanalytic Theory } \\
\text { - Cognitive Theory } \\
\text { - Generalized Event Theory } \\
\text { - Systems Theory } \\
\text { - Non-linear Dynamic } \\
\text { Systems Theory (also } \\
\text { known as Complexity } \\
\text { or Chaos Theory) }\end{array}$ & 37 & Applegate, 2004 \\
\hline Restorative Justice & 36 & Crampton, 2004 \\
\hline Decision-making Theory & 36 & Smith \& Moen, 2004 \\
\hline Life Course Theory & 36 & Crosnoe \& Elder, 2004 \\
\hline Marx Alienation Theory & 35 & Ferguson \& Lavalette, 2004 \\
\hline Procedural Justice & 35 & Neff, 2004 \\
\hline Field Instruction & 35 & Fox, 2004 \\
\hline Trauma Theory & 35 & Mohr, 2004 \\
\hline Psychoanalytic & 34 & Jones, 2004 \\
\hline Transtheoretical Model of Change & 34 & McGuire, 2004 \\
\hline Capitol Theory & 34 & Ferguson, 2004 \\
\hline Psychoanalytic Theory & 33 & Bright, 2004 \\
\hline Family Stress Theory & 33 & Abbott et al., 2004 \\
\hline Responsive Regulation & 33 & Burford \& Adams, 2004 \\
\hline Social Constructionism & 33 & Montgomery, 2004 \\
\hline Health Belief Model & 33 & Sullivan et al., 2004 \\
\hline Trauma & 33 & $\begin{array}{l}\text { Regehr, Hemsworth, Leslie, Howe \& } \\
\text { Chau, } 2004\end{array}$ \\
\hline Attachment Theory & 32 & Bennett, 2004 \\
\hline Personal Authority in Family System & 32 & Lawson \& Brossart, 2004 \\
\hline Relational Theory & 32 & Dietz \& Thompson, 2004 \\
\hline Self-in-Relation Theory & 31 & $\begin{array}{l}\text { Lesser, O'Neil, Burke, Scanlon, Hollis, } \\
\& \text { Miller, } 2004\end{array}$ \\
\hline Stigma Theory, Feminist Theory & 31 & Lipton, 2004 \\
\hline Lacanian Analytic Theory & 31 & Baylis, 2004 \\
\hline Theory of Control Mastery & 31 & Nol, 2004 \\
\hline \multicolumn{3}{|l|}{ Social Learning Theory } \\
\hline - Self-Psychological Theory & 31 & Dick, 2004 \\
\hline Psychodynamic Theory & 31 & Brandell \& Ringol, 2004 \\
\hline $\begin{array}{l}\text { Triangle of Political Space } \\
\text { - Restorative Justice }\end{array}$ & 31 & Kelly, 2004 \\
\hline
\end{tabular}




\begin{tabular}{|c|c|c|}
\hline Theory & Rating & Author \& Year of Publication \\
\hline Community Family Therapy & 31 & Rojano, 2004 \\
\hline Meta-theory & 30 & Houston, 2004 \\
\hline Grief Theory & 30 & Brownlee \& Oikonen, 2004 \\
\hline Psychoanalytic Theory & 30 & Alperin, 2004 \\
\hline Gender Entrapment Theory & 30 & Bent-Goodley, 2004 \\
\hline Ethnic Identity Theory & 30 & Margaret O'Donoghue \\
\hline \multicolumn{3}{|l|}{ - Racial Identity Theory } \\
\hline \multicolumn{3}{|l|}{$\begin{array}{l}\text { - Black Racial Identity } \\
\text { Development (BRID) }\end{array}$} \\
\hline \multicolumn{3}{|l|}{$\begin{array}{l}\text { - *White Racial Identity } \\
\text { Development (WRID) }\end{array}$} \\
\hline Gender-role Androgyny Theory & 30 & Utz et al., 2004 \\
\hline Imposter Phenomenon & 29 & Castro et al., 2004 \\
\hline $\begin{array}{l}\text { Empowerment Theory) } \\
\text { (Afrocentric Perspective }\end{array}$ & 28 & $\begin{array}{l}\text { Manning, Cornelius, \& Okundaye, } \\
2004\end{array}$ \\
\hline Political Economy Theory & 28 & Mulroy \& Tamburo, 2004 \\
\hline Emancipatory Disability Theory & 27 & O'Connor et al., 2004 \\
\hline Attachment Theory & 27 & Wampler, Riggs \& Kimball, 2004 \\
\hline Critical Theory & 26 & Keenan, 2004 \\
\hline Organization in Environment & 26 & Mulroy, 2004 \\
\hline Attachment Theory & 26 & Allen \& Baucom, 2004 \\
\hline Attachment Theory & 25 & Gubman, 2004 \\
\hline Attachment Theory & 25 & Ringel, 2004 \\
\hline \multicolumn{3}{|l|}{ - Object Relations Theory } \\
\hline \multicolumn{3}{|l|}{ - Intersubjective Theory } \\
\hline Psychoanalytic Theory & 24 & Steger, 2004 \\
\hline Role Model Theory & 24 & Baum, 2004 \\
\hline Theory of Change & 23 & Little \& Girvin, 2004 \\
\hline Ecosystemic & 23 & Coffey, 2004 \\
\hline Psychoanalytic Theory & 22 & Sanville, 2004 \\
\hline Feminist Theory & 20 & Blume, 2004 \\
\hline
\end{tabular}

There are several limitations inherent to this type of study. It is necessary to consider differences in editorial policy and practice regarding the level of importance placed on theory discussion, which undoubtedly varies from journal to journal. These differences in editorial policy and practice represent numerous potential biases that would directly affect our results. One possibility to consider is that authors may limit their discussion of theory due to the restrictions placed on manuscript length, often 20 pages or less, by peer-reviewed journals. An alternative explanation is that authors are submitting articles that incorporate theory 
discussion, and these articles are being rejected for publication. Consideration of articles that are rejected for publication would be an interesting addition to future studies of this nature.

Some additional limitations of this study that necessitate consideration prior to any conclusions drawn about theory progression based on our data are numerous. First, while the authors obtained inter-rater reliability scores at two points in this study, the ratings were subjective in nature. Thus, there is most likely some variability in scores assigned during TDE and TDF classification (Table 2), as well as during evaluation of theory quality (Table 1). Second, the criteria included in Tables 1 and 2 were developed by Daley and others (2005). Although these scales were developed based on the previous work of Daley et al., 2005 and factors blended from the models described in the "evaluation of theory quality and progression" section, it is necessary to recognize biases inherent to this type of process. Third, our data reports on only 37 journals reviewed for this study. There are numerous social work journals, as evidenced by the reduction process in this study, which decreased the original 268 journals selected for review to the 37 journals ultimately reviewed. Related to this limitation is the fact that we limited our review to peer-reviewed journal articles and did not consider other types of publications. Fourth, it is highly likely, given the interdisciplinary nature of the profession, that many social work theorists publish articles containing more extensive theoretical discussion in non-social work journals.

\section{CONSIDERATIONS FOR FUTURE STUDIES}

Studies of this nature are limited. While reviews of the literature resulted in the identification of articles relating studies of a similar nature (Cnaan, Caputo, \& Shmuely, 1994; Furr, 1995; Gomory, 2001; Lindsey \& Kirk, 1992; Sellers, Mathiesen, Perry, \& Smith, 2004), these authors did not evaluate the quality of theory discussion or progression within social work journals. Rather, the focus of these authors was more relevant to the role of theory in social work research and practice (Gomory, 2001), prestige of journals (Cnaan et al., 1994), the role of social work journals in the development of the profession (Lindsey \& Kirk, 1992) and assessing journal quality based on citation counts (Furr, 1995; Lindsey \& Kirk, 1992). To the best of our knowledge, Daley and others' pilot study (2005) was the first of its kind; the current study is a follow-up to that work.

Considering this was a pilot study, there were many lessons learned, and the authors offer several suggestions for future studies of this nature. First, while Table 3 represents the immense diversity of theories identified within the articles reviewed and evaluated for this study, it is difficult to discern from our results the contribution that these articles make to the progression of a particular theory. A review of the theories listed in Table 3 indicate a discussion of micro, mezzo, and macro level theories, incorporating the inclusion of well-known theories (attachment theory, systems theory, feminist theory, psychoanalytic theory) as well as highly focused theories (gender-role androgyny theory, grief theory, queer theory, theory of mindful space). Thus, the development of methodology to ascertain the progression of a particular theory would be a beneficial addition to future studies of this nature. 
Second, as noted in the "limitations" section, interpretations based on our results are limited to articles published in 2004 that appeared in the 37 journals reviewed for this study. Therefore, the consideration of alternative methods of journal/article selection represents the potential for increasing the knowledge base with regard to theory discussion and progression in social work journals. As mentioned previously, it would be interesting to obtain articles submitted and subsequently rejected for publication by various social work journals. Evaluating articles rejected for publication based on the criteria utilized in the current study would provide additional information pertaining to the level of importance placed on theory discussion and progression by social work journal editorial boards. An additional alternative method of selection would be to review journals classified by Baker (1992) as the "core of the social work journal network" (p. 160). Baker (1992) identified five journals considered the "core of the social work journal network," including Social Work, Social Service Review, Families in Society, the Journal of Social Work Education, and Social Work Research and Abstracts (now two separate journals, Social Work Research and Social Work Abstracts) (p. 160). Future studies could compare theory discussion and progression as found in articles published in these journals and classified by Baker (1992) as central to the social work profession to other "non-core" social work journals.

Lastly, the authors recommend that follow-up to this study be conducted in a quasi longitudinal manner to assess the consistency or lack thereof of the degree of theory discussion and progression in social work journals from one year to the next. An alternative to considering undertaking concurrent with future studies that attempt to ascertain the degree of consistency of theoretical discussion in social work journals would be to add the component of comparing social work journals with other professions' journals. The purpose of this additional component would be to determine whether social work journals contain more or less theory discussion than the profession chosen for the comparison.

\section{DISCUSSION}

According to Sellers and colleagues (2004), for numerous reasons, evaluating the quality of social work journals is an important aspect of professional social work. Explanations offered by the authors (Sellers et al., 2004) in support of this contention include:

1. the tremendous increase in the number of social work journals makes it nearly impossible for professionals to read or evaluate all available publications.

2. as a multidisciplinary profession, social work professionals face the additional challenge of reading, evaluating, and writing for journals across diverse fields.

3. the assessment of journals that are considered to be of high quality offers guidance and direction to researchers, writers, and readers, because these publications would presumably model strong research methods, conceptual rigor, and valuable techniques of presentation.

4. for many faculty, being published in prestigious journals may increase the likelihood of pay raises, promotions, and recognition from colleagues (p. 143). 
While Sellers and colleagues are referring to the quality of social work journals in general, rather that specifically addressing the quality of theory discussion within social work journals, we contend that evaluation of the quality of theory discussion is imperative for the same reason as well as additional reasons. Marsh (2002) suggests that the role and function of social work journals is a long-standing disparity among social work professionals, especially in consideration of those academic publications whose focus is limited with regard to practice application. Given that theory provides practitioners with a systematic method to conceptualize information about individuals, their behavior, and the contexts in which they interact and live, we assert that social workers need to make a conscious effort to critically analyze and consider the counterevidence to the theoretical assumptions upon which practitioners' base clinical decisions and actions (Lindsey \& Kirk, 1992).

\section{References}

Abbott, D., Sharma, S., \& Verma, S. (2004). The emotional environment of families experiencing chronic poverty in India. Journal of Family and Economic Issues, 25(3), 387-409.

Allen, K. (2004). Janet Saltzman Chaftez plenary: Discussant comments. Journal of Family Issues, 25(7), 984-989.

Allen E.S., \& Baucom, D.H. (2004). Adult attachment and patterns of extradyadic involvement. Family Process, 43(4), 467-488.

Alperin, R.M. (2004). Toward an integrated understanding of dreams. Clinical Social Work Journal, 32(4), 451-469.

Andermahr, S., Lovell, T., \& Wolkowitz, C. (1997). A concise glossary of feminist theory. New York, NY: St. Martin Press, Inc.

Anguiano, R. (2004). Families and schools: The effect of parental involvement on high school completion. Journal of Family Issues, 25(1), 61-85.

Applegate, J.S. (2004). Full circle: Returning psychoanalytic theory to social work education. Psychoanalytic Social Work, 11(1), 23-36.

Baber, K. (2004). Building bridges: Feminist research, theory, and practice. Journal of Family Issues, 25(7), 978-983.

Baker, D.R. (1992). A structural analysis of the social work journals network: 1985-1986. Journal of Social Service Research, 15(3/4), 153-168.

Bartlett, H.M. (2003). Working definition of social work practice. Research on Social Work Practice, 13(3), 267-270.

Baum, C. (2004). The long-term effects of early and recent maternal employment on a child's academic achievement. Journal of Family Issues, 25(1), 29-60.

Baylis, P.J. (2004). Social work's protracted identity crisis. Psychoanalytic Social Work, 11(1), 55-69.

Bennett, S. (2004). Viewing telephone therapy through the lens of attachment theory and infant research. Clinical Social Work Journal, 32(3), 239-250.

Bent-Goodley, T. (2004). Perceptions of domestic violence: A dialogue with African American women. Health and Social Work, 29(4), 307-316.

Blume, L. (2004). Bridging gender theory research: A symposium on feminist theory construction and research methodology. Journal of Family Issues, 25(7), 959-962. 
Brandell. J., \& Ringel, S. (2004). Psychodynamic perspectives on relationship: Implications of new findings from human attachment and the neurosciences for social work education. Families in Society: The Journal of Contemporary Human Services, 85(4), 549-556.

Bright, C. (2004). Deconstructing reparative therapy: An examination of the processes involved when attempting to change sexual orientation. Clinical Social Work Journal, 32(4), 471-481.

Brownlee, K., \& Oikonen, J. (2004). Toward a theoretical framework for perinatal bereavement. British Journal of Social Work, 34(4), 517-529.

Burford, G., \& Adams, P. (2004). Restorative justice, responsive regulation, and social work. Journal of Sociology and Social Welfare, 31(1), 7-26.

Burlae, K.K. (2004). The theory of mindful space: Identifying, understanding, and preventing violence. Affilia, 19(1), 85-98.

Castro, D.M., Jones, R.A., \& Mirsalimi, H. (2004). Parentification and imposter phenomenon: An empirical investigation. The American Journal of Family Therapy, 32(3), 205-216.

Chafetz, J. (2004a). Bridging feminist theory and research methodology. Journal of Family Issues, 25(7), 963-977.

Chafetz, J. (2004b). Reply to comments by Walker, Baber, and Allen. Journal of Family Issues, 25(7), 995-997.

Cnaan, R.A., Caputo, R.K., \& Shmuely, Y. (1994). Senior faculty perceptions of social work journals. Journal of Social Work Education, 30(2), 185-199.

Coffey, E.P. (2004). The heart of the matter: Integration of ecosystemic family therapy practices with systems of care mental health services for children and families. Family Process, 43(2), 161-172.

Corcoran, J., \& Nichols-Casebolt, A. (2004). Risk and resilience ecological framework for assessment and goal formulation. Child and Adolescent Social Work Journal, 21(3), 211-235.

Cordon, J., \& Somerton, J. (2004). The trans-theoretical model of change: A reliable blueprint for assessment in work with children and families? British Journal of Social Work, 34(7), 1025-1044.

Cottrell, B., \& Monk, P. (2004). Adolescent-to-Parent Abuse: A qualitative overview of common themes. Journal of Family Issues, 25(8), 1072-1095.

Crampton, D. (2004). Family interventions in child protection: Learning from contextual rated strategies. Journal of Sociology and Social Welfare, 31(1), 175-198.

Crosnoe, R., \& Elder, G. (2004). Family dynamics, supportive relationships, and educational resilience during adolescence. Journal of Family Issues, 25(5), 571-602.

Daley, J.G., Peters, J., Taylor, R., Hanson, V., \& Hill, D. (2005). Theory discussion in social work journals: A preliminary study. Advances in Social Work, 7(1), 1-19.

Dick, G.L. (2004). The fatherhood scale. Research on Social Work Practice, 14(2), 80-92.

Dietz, C., \& Thompson, J. (2004). Rethinking boundaries: Ethical dilemmas in the social worker-client relationship. Journal of Progressive Human Services, 15(2), 1-24.

Ferguson, I., \& Lavalette, M. (2004). Beyond power discourse: Alienation and social work. British Journal of Social Work, 34(3), 297-312.

Ferguson, K. (2004). Measuring and indexing social capitol in relation to children's street work in Mexico: The role of culture in shaping social capitol indicators. Journal of Sociology and Social Welfare, 31(4), 81103.

Finn, J.L., \& Jacobson, M. (2003). Just practice: Steps toward a new social work paradigm. Journal of Social Work Education, 39(1), 57-78.

Fischer, J. (1973). A framework for the analysis and comparison of clinical theories of induced change. In J. Fischer (Ed.), Interpersonal helping (pp. 110-130). Springfield, IL: Charles C. Thomas.

Fox, R. (2004). Field instruction and the mature student. Journal of Teaching in Social Work, 24(3-4), 113129.

Furr, L.A. (1995). The relative influence of social work journals: Impact factors vs. core influence. Journal of Social Work Education, 31(1), 38-45. 
Gomory, T. (2001). A fatalistic response to Thyer's theory of theory-free empirical research in social work practice. Journal of Social Work Education, 37(1), 26-50.

Gubman, N. (2004). Disorganized attachment: A compass for navigating the confusing behavior of the "difficult-to-treat" patient. Clinical Social Work Journal, 32(2), 159-169.

Houston, S. (2004). Garrett contra Ferguson: A meta-theoretical appraisal of the "rumble in the jungle." British Journal of Social Work, 34(2), 261-267.

Jones, K. (2004). Assessing psychological separation and academic performance in non-resident-father and resident-father adolescent boys. Child and Adolescent Social Work Journal, 21(4), 333-354.

Kahng, S.K., \& Mowbray, C. (2004). Factors influencing self-esteem among individuals with severe mental illness: Implications for social work. Social Work Research, 28(4), 225-236.

Keenan, E. (2004). From sociocultural categories to socially located relations: Using critical theory in social work practice. Families in Society: The Journal of Contemporary Human Services, 85(4), 539-538.

Kelly, K. (2004). Working together to stop domestic violence: State-community partnerships and the changing meaning of public and private. Journal of Sociology and Social Welfare, 31(1), 27-47.

Kroska, A. (2004). Divisions of domestic work: Revising and expanding the theoretical explanations. Journal of Family Issues, 25(7), 900-932.

Landry-Meyer, L., \& Newman, B. (2004). An exploration of the grandparent caregiver role. Journal of Family Issues, 25(8), 1005-1025.

Lawson, D.M., \& Brossart, D.F. (2004). The developmental course of personal authority in the family system. Family Process, 43(3), 391-409.

Lesser, J.G., O’Neil, M.R., Burke, K.W., Scanlon, P., Hollis, K., \& Miller, R. (2004). Women supporting women: A mutual aid group fosters new connections among women in midlife. Social Work with Groups, 27(1), 75-88.

Lindsey, D., \& Kirk, S.A. (1992). The role of social work journals in the development of a knowledge base for the profession. Social Service Review, 66(2), 295-310.

Lipton, B. (2004). Gay men living with non-HIV chronic illnesses. Journal of Gay and Lesbian Social Services, 17(2), 1-23.

Littel, J.H., \& Girvin, H. (2004). Ready or not: Uses of the stages of change model in child welfare. Child Welfare, 83(4), 341-368.

Mack-Canty, C., \& Wright, S. (2004). Family values as practiced by feminist parents. Journal of Family Issues, 25(7), 851-880.

Manning, M., Cornelius, L., \& Okundaye, J. (2004). Empowering African Americans through social work practice: Integrating an Afrocentric perspective, ego psychology, and spirituality. Families in Society: The Journal of Contemporary Human Services, 85(2), 229-235.

Marsh, J. (2002). Using knowledge about knowledge utilization. Social Work, 47(2), 101-104.

McGuire, L.E. (2004). The transtheoretical model: Welfare to work as a change process. Journal of Human Behavior in the Social Environment, 10(2), 33-56.

McPhail, B. (2004). Questioning gender and sexuality binaries: What queer theorists, transgendered individuals, and sex researchers can teach social work. Journal of Gay and Lesbian Social Services, 17(1), 3-21.

Mohr, S. (2004) Creating space for radical trauma theory in generalist social work education. Journal of Progressive Human Services 15(2), 45-55.

Montgomery, E. (2004). Tortured families: A coordinated management of meaning analysis. Family Process, 43(3), 349-371.

Mulroy, E.A. (2004). Theoretical perspectives on the social environment to guide management and community practice: An organization in environment approach. Administration in Social Work, 18(2), 78-96.

Mulroy, E.A., \& Tamburo, M.B. (2004). Nonprofit organizations and welfare to work: Environmental turbulences and organizational change. Administration in Social Work, 28(3/4), 111-135.

NASW. (1997). An author's guide to social work journals (4 ${ }^{\text {th }}$ ed.). Washington, D.C.: NASW Press.

Neff, R. (2004). Achieving justice in child protection. Journal of Sociology and Social Welfare, 31(1), 137-154. 
Nol, J. (2004). Control-mastery: Theory and application. Psychoanalytic Social Work, 11(1), 37-54.

O'Connor, D., Young, J., \& Saul, M. (2004). Living with paraplegia: Tensions and contradictions. Health and Social Work, 29(3), 207-218.

O'Donoghue, M. (2004). Racial and ethnic identity development in white mothers of biracial, black-white children. Affilia, 19(1), 68-84.

Payne, M. (2005). Modern social work theory, $3^{\text {rd }}$ Ed. Chicago: Lyceum Books.

Pennell, J. (2004). Family group conferencing in child welfare: Responsive and regulatory interfaces. Journal of Sociology and Social Welfare, 31(1), 117-135.

Pinderhughes, E. (1996). Direct practice overview. Encyclopedia of Social Work (19 ${ }^{\text {th }}$ ed.). 740-751. Washington, D.C.: NASW.

Regehr, C., Hemsworth, D., Leslie, B., Howe, P., \& Chau, S. (2004). Predictors of post traumatic stress in child welfare workers: A linear structural equation model. Child and Youth Services Review, 26(6), 246331.

Richman, J.M., \& Cook, P.G. (2004). A framework for teaching family development for the changing family. Journal of Teaching in Social Work, 24(1/2), 1-18.

Ringel, S. (2004). The man without words: Attachment style as an evolving dynamic process. Psychoanalytic Social Work, 11(2), 71-82.

Robbins, S.P., Chatterjee, P., \& Canda, E.R. (1999). Ideology, scientific theory, and social work practice. Families in Society: The Journal of Contemporary Human Services, 80, 374-384.

Rojano, R. (2004). The practice of community family therapy. Family Process, 43(1), 59-76.

Rosen, A., Proctor, E.K., \& Staudt, M. (2003). Targets of change and interventions in social work: An empirically based prototype for developing practice guidelines. Research on Social Work Practice, 13(2), 208233.

Sanville, J.B. (2004). On the impossibility of getting it right the first time. Clinical Social Work Journal, 32(1), 23-38.

Schriver, J.M. (2001). Human behavior and the social environment: Shifting paradigms in essential knowledge for social work practice ( $3^{\text {rd }}$ ed.). Boston, MA: Allyn \& Bacon.

Schriver, J.M. (2004). Human behavior and the social environment: Shifting paradigms in essential knowledge for social work practice ( $4^{\text {th }}$ ed.). Boston, MA: Allyn \& Bacon.

Sellers, S.L., Perry, R., Mathiesen, S.G., \& Smith, T. (2004). Evaluation of social work quality: Citation versus reputation approaches. Journal of Social Work Education, 40(1), 143-160.

Smith, D., \& Moen, P. (2004). Retirement satisfaction for retirees and their spouses. Journal of Family Issues, 25(2), 262-285.

Steger, G.S. (2004). The mind of a stranger: A philosophic contribution to bi-cultural psychotherapy. Clinical Social Work Journal, 32(1), 9-21.

Sullivan, K.T., Pasch, L.A., Cornelius, T., \& Cirigliano, E. (2004). Predicting participation in premarital prevention programs: The health belief model and social norms. Family Process, 43(2), 175-193.

Thyer, B.A. (1994). Are theories for practice necessary? No! Journal of Social Work Education, 30(2), 148-151.

Thyer, B.A. (2001). Point/Counterpoint: What is the role of theory in research on social work practice? Journal of Social Work Education 37(1), 9-25.

Turner, FJ. (1996). Theory and social work treatment. In Turner, FJ. (Ed.)., Social work treatment: Interlocking theoretical approaches ( $4^{\text {th }}$ ed., pp. 1-17,). Free Press.

Utz, R., Reidy, E., Carr, D., Nesse, R., \&Wortman, C. (2004). The daily consequences of widowhood:The role of gender and intergenerational transfers on subsequent housework performance. Journal of Family Issues, 25(5), 683-712.

Vandervalk, I., Spruijt, E., De Goede, M., Meeus, W., \& Maas, C. (2004). Marital status, marital process, and parental resources in predicting adolescents' emotional adjustment. Journal of Family Issues, 25(3), 291317. 
Vandsburger, E., \& Biggerstaff, M.A., (2004). Evaluation of the stress adjustment and adaptation model among families reporting economic pressure. Journal of Family Social Work, 8(2), 65-84.

Walker, A. (2004). Methods, theory, and the practice of feminist research. Journal of Family Issues, 25(7), 990-994.

Wampler, K.S., Riggs, B., \& Kimball, T.G. (2004). Observing attachment behavior in couples: The adult attachment behavior Q-Set (AABQ). Family Process, 43(3), 315-335.

Witkin, S.L., \& Gottschalk, S. (1988). Alternative criteria for theory evaluation. Social Service Review, 62, 211-224.

Wood, M. (2004). The gay male gaze: Body image disturbance and gender oppression among gay men. Journal of Gay and Lesbian Social Services, 17(2), 43-62.

Zuo, J. (2004). Shifting the breadwinning boundary: The role of men's breadwinner status and their gender ideologies. Journal of Family Issues, 25(6), 811-832.

\section{Author's Note:}

Address correspondence to: Carolyn S. Gentle-Genitty, MSW, doctoral student, School of Social Work, Indiana University, 902 West New York Street, Indianapolis, IN 46202-5156, USA. e-mail: cgentleg@iupui.edu. 